\title{
Education in China Since Mao
}

\author{
WILLIAM G. SAYWELL*
}

\begin{abstract}
Policies in Chinese education, particularly higher education, have undergone major shifts since 1949 in response to general swings in Chinese policy, ideological debates and the political fortunes of different leaders and factions. These changes have involved shifts in emphasis between "redness" and "expertness", between education as a party device designed to inculcate and sustain revolutionary values and education as a governmental instrument used to promote modernization. In the most recent period since Mao's death and the "Gang of Four's" ouster in the fall of 1976, there has been a return to pragmatism with the radical policies and stress on political goals of the Cultural Revolution period giving way to a renewed emphasis on developing professional and technical skills. These objectives are being promoted by the reintroduction of earlier moderate policies governing curricula, admission standards and academic administration and by extraordinary measures, including international educational exchanges, designed to overcome the Cultural Revolution's disruptive impact. These new policies have provoked some criticism from those concerned about elitist aspects of the current system and a reduced commitment to socialist values. Since educational policy is highly sensitive to shifting political currents, future changes in this area will serve as a barometer of new political trends.
\end{abstract}

\section{RÉSUMÉ}

La politique de l'enseignement en Chine, particulièrement l'enseignement supérieur, a subi des changements majeurs depuis 1949 en réponse aux va-et-vient généraux de la politique chinoise, aux débats idéologiques et à la fortune politique des différents leaders et des dissensions. Ces changements ont impliqués des déplacements d'accent entre le fait d'être "rouge" et le fait d'être "expert", entre l'éducation en tant qu'appareil d'un parti visant à inculquer et supporter des valeurs révolutionnaires et une éducation en tant qu'instrument du gouvernement employé à promouvoir la modernisation. Dans la plus récente période depuis la mort de Mao et l'éviction du "Gang des Quatre" en automne 1976, il y a eu un retour au pragmatisme avec la politique radicale et un accent mis sur les buts politiques de la période de la Révolution Culturelle cédant la place à une importance renouvelée accordée au développement des aptitudes professionelles et techniques. Ces objectifs sont

* Vice-Provost, University of Toronto. The author gratefully acknowledges financial support which allowed him to travel to China, from the University of Toronto/York University Joint Centre on Modern East Asia and the Social Sciences and Humanities Research Council. 
promus par la réintroduction d'une politique modérée, plus ancienne, régissant les curriculums, les standards d'admission et l'administration académique, et par mesures extraordinaires, incluant des échanges éducatifs internationaux, visant à surmonter l'impact perturbateur de la Révolution Culturelle. Cette nouvelle politique a provoqué quelques critiques dans les parties concernées par les aspects élitistes du système actuel et d'un sentiment de responsabilité réduit vis-à-vis des valeurs socialistes. Puisque la politique éducative est extrêmement sensible aux changements de courants politiques, les changements futurs dans ce domaine serviront de baromètre dans les nouvelles tendances politiques.

\section{Introduction: Shifts in Education Policies, 1949-1976}

Policies in Chinese education, particularly higher education, have undergone major periodic shifts since the establishment of the People's Republic of China in October, 1949. Few other major policy areas have been as sensitive to the general swings in Chinese policy, ideological debates and the political fortunes of different leaders and factions. This is hardly surprising. As a developing nation the critical importance education plays as a steering force in the nation's development is obvious. As a revolutionary socialist society its leaders have strongly held convictions about the values and norms, as well as the professional training, education must provide. Education is an explicit device of the party designed to inculcate and sustain revolutionary values and Marxist-Leninist theories, as well as an instrument of the state used to promote its modernization. The duality of 'redness' and 'expertness' has been at the essence of Chinese educational objectives, while swings in emphasis between the two have been a major characteristic of policy change. As a controlled society (some would argue totalitarian), leaders and leadership groups have been able to impose sudden and dramatic shifts and reversals in the field of education policy as in other areas.

In the early 1950's Chinese policies, including those in Chinese education, particularly at the post-secondary level, essentially followed the Soviet model. This emphasized scientific and technological training directed at the needs of an industrializing society. For example, in 1949 China had 180 institutions of higher education enrolling 80,000 students. By 1957 enrollment had jumped to $440,000 .^{1}$ The Chinese Academcy of Sciences, the national organization primarily responsible for the training of research scientists, had thirty-one research institutes in 1952 and 170 in $1958 .^{2}$

When Mao abandoned much of the Soviet model in the Great Leap Forward of 1958, policies in education shifted accordingly. Less priority was given to the advanced training of a scientific and technological group needed to manage an industrializing economy. Politics and class background were introduced as criteria for admission to university. Priority was given programmes which aimed at achieving mass literacy, providing local initiative, expanding rural educational opportunities, encouraging curricular and structural innovation and politicizing education at all levels. Many of these policies including programmes like the part-work/part-study schemes had their roots in the Chinese Communists' revolutionary tradition long before Liberation and had been continued in the early 1950's. But they were given renewed priority in the great Leap period. Enrollment in China's primary schools almost doubled between 1957 and 1965 , jumping from $51,000,000$ in 1952 to $64,000,000$ in 1957 and $116,000,000$ in $1965 .^{3}$ This represented $84.7 \%$ of 


\section{Education in China since Mao}

school age children. ${ }^{4}$ In the same period middle (secondary) school enrollment increased from $3,100,000$ to $7,000,000$ in 1957 and $14,400,000$ in $1965 .^{5}$ The failure of the Great Leap generally and the economic difficulties that followed led to a retreat in these educational priorities along with a major shift in the country's economic policies as a whole. As China moved to a more moderate set of policies in the recovery years of the early 1960's, education policies began to shift their emphasis away from the more politically oriented ones of the Leap years to those associated with economic development. While mass literacy and universal primary education remained important targets, a renewed emphasis was given higher education, particularly in the training of scientists and engineers in both universities and research institutes. By 1965 university enrollment had reached $670,000 .^{6}$

Community run primary and middle schools offered at least some education to most at the local level. But academic quality and opportunities for professional development and mobility rested in a state run system which included "key" schools at each level." To the key schools went the best teachers, students and equipment. Unified entrance examinations channelled the best students from each level into the key institutions at the next level. Class background and political activism remained criteria for admission to universities, but the basic evaluation was made on the academic record of the student, particularly in the form of his or her mark on the college entrance exam. The quality of middle and primary schools was largely judged on the basis of the percentage of their students who entered college. At the top of the hierarchy China's best universities were designated "key" universities and made directly responsible to the Ministry of Education. In 1965 education in China, especially higher education, favored city over countryside, intellectual ability over class background or political activism and 'expert' over 'red'.

To Mao Zedong these policies, like many at that time, were 'revisionist' and the work of 'capitalist roaders' in the party. China and especially its youth had to be redirected away from the revisionist model of the Soviet Union with whom China had fallen out in 1960 , to a purer Chinese revolutionary one. In 1966 he launched the Great Proletarian Cultural Revolution. In June of that year university classes were suspended, initially for six months, to revise curricula, teaching methods and admission procedures. In the summar of 1967 a few institutes of higher education such as the Aeronautics Institute of Peking resumed limited work, but essentially China's system of higher education remained closed. In October, 1967 a central directive ordered universities, secondary and primary schools everywhere to commence classes immediately. Primary and middle schools which had also been widely suspended resumed classes at different points between then and 1969. But China's universities remained torn by revolutionary upheaval.

In July, 1968 a new directive from Mao published in the People's Daily explained what kind of higher education China should have:

It is still necessary to have universities: here I refer mainly to colleges of science and engineering. However, it is essential to shorten the length of schooling, revolutionize education, put proletarian politics in command and take the road of the Shanghai Machine Tools Plant in training technicians from among the workers. Students should be selected from among the workers and peasants with practical experience, and they should return to production after a few years' study. ${ }^{8}$

The report in which this directive appeared was vitally important, highlighting major points 
that would serve as the guidelines for most institutions as they reopened. It emphasized the need for students to engage in productive labour before entering university, to combine study and labour, use workers in the classroom as teachers and place greater emphasis on class background and ideological purity as criteria for admission. It also pointed to the production unit as the crucial level at which recommendation of students wanting to enter university should take place.

In August, 1968 "worker-peasant Mao Zedong propaganda teams" entered universities throughout the country. Under the combined pressure and direction of these teams comprised of local workers, and units of the People's Liberation Army (PLA) stationed in China's major universities, most institutions spent much of 1968 and 1969 struggling to re-establish order and prepare for the resumption of classes. ${ }^{9}$ Revolutionary committees replaced the decimated party and the purged administration as the political and administrative authority. Slowly China's universities, some in 1970 and others in 1971 or 1972, resumed undergraduate education.

For four or five years China had been without university education. Many young people who wanted to attend university simply lost the opportunity forever. China's professors and researchers had been denied access to libraries and laboratories. Many suffered horribly at the hands of Red Guard fanatics, while others spent long periods in manual labour and political study in the countryside. Some were killed or committed suicide. Library collections, laboratories and personal research materials were often damaged and sometimes destroyed. Except in a few select areas, usually of military significance, little serious research was done and no significant direct contact with the international scientific community and its publications maintained. While most of China's professors went back to the classroom between 1970 and 1973, the next few years until Mao's death in the autumn of 1976 were extremely frustrating. New education policies known collectively as the 'revolution in education' were strongly influenced by the radicals, in particular the "Gang of Four" led by Mao's wife Jiang Qing. At all levels these policies were designed to end the so called "three divorcements" or "separations" of earlier Chinese education from proletarian politics, manual labour and the workers and peasants.

At the primary and middle school level the policies of the Cultural Revolution decade (1966-76) emphasized getting some education to everyone rather than better education to the best qualified. The six/six year primary/middle school period was reduced to a five/five year system. Entrance exams were abolished, curriculum condensed and simplified, practical training, manual labour, political study and activism stressed. Political reports replaced academic ones and failure was virtually unheard of. The key school system was dismantled; professionally well qualified teachers were often replaced with politically acceptable but academically unqualified teachers, frequently not themselves middle school graduates. There was wide experimentation with factory-run schools, 'on the spot' education and the use of workers and peasants for some classroom instruction.

Although academic quality was sacrificed, some very real progress appears to have been made in achieving universal primary education in all but the most remote areas, and getting a higher percentage of the nation's youth, particularly from worker/peasant backgrounds into some area of secondary education. Schools were relocated at the basic production units, more schools were established, attendance rules were made more flexible especially in rural schools to correspond with the agricultural season, financial 
aid was given poorer children and increased opportunities were created for 'irregular' or part-time study. Enrollment in middle schools almost quadrupled during the decade reaching $58,280,000$ in $1977 .^{10}$

Changes in the primary and middle school system had a major impact on the universities. But specific new policies for higher education had an even more profound influence on the quality of university education in the Cultural Revolution decade. ${ }^{11}$ The first major change was the reduction in the length of programmes from the usual five years in science and engineering to four, and from four to three years in liberal arts. Students normally were not allowed to enter university directly from middle school, having first to be "tempered by labour" for at least two years in the nation's communes, factories or PLA. ${ }^{12}$ Admission was possible for students who had five years experience in "productive labour" even though they were not graduates of Senior Middle schools.

In the early 1970's, university education in China characteristically involved a three year programme for a student body, most of whom had a junior middle school education, that is approximately a total of eight years of pre-university schooling, interrupted by several years work. Many of the students in medical programmes, the length of which had been cut from five to four and sometimes three years, had entered after some para-medical experience usually as bare-foot doctors in the countryside. Many of these students had only a primary or middle school education, and a few months of paramedical training before entering a university programme that typically included only a year of basic science study before the final two years of clinical and internship work.

Perhaps the most dramatic changes were in the admission criteria and procedures. Provincial bureaus of education distributed the number of college places among counties and cities, which in turn, allocated them to the work units. "This was done with a view to making up particular deficiencies of skills in communes, factories, and other units, on the assumption that young people would return to the locality after graduation."13 Entrance exams were abolished. The new admission system involved four stages: voluntary application, recommendation by the masses, approval by the leadership and re-evaluation by the university. At the second step candidates who had applied were considered by their fellow workers and a recommendation made to the leadership of the production unit in which all worked. These recommendations were screened by the leadership who forwarded their choice to the universities which made the final selection. The leadership stage allowed for considerable abuse of the system as cadres in communes and factories often chose their own relatives in a practice known as "using the back door".

Three major criteria were used in the selection process: physical fitness, 'cultural level' (i.e. intellectual ability and academic achievement) and political consciousness. It was the third of these that was critical. In general it was much more than an evaluation of political activism or ideological sophistication. Essentially it was a kind of character reference in which the candidates' fellow workers were expected to judge them as citizens in terms of such things as their selflessness, interpersonal relations, leadership qualities, dedication, conscientiousness and so on. Only the sons and daughters of workers, peasants and soldiers could apply, although children of other urban groups were eligible by virtue of their two years of labour in the countryside allowing them to be reclassifed as peasants!

Changes in the form and content of university education were also dramatic. Exams, or at least what were referred to as "surprise attack" exams, were abolished. Textbooks and other teaching materials were rewritten to incorporate the latest ideological position. 
In all disciplines written materials and lectures were expected to take on a more applied or practical bent. A major emphasis was placed on political study and manual labour for both faculty and students. Universities had factories and workshops on their campuses and were associated with others off-campus ${ }^{14}$ Practice varied greatly from university to university. In the period of most radical experimentation, 1974-76, large numbers of Beida (Peking University) and Qinghua University students spent much of the year off campus. For example, several hundred Beida freshmen spent the entire 1974.75 academic year at the university's farm. At Shanghai's Fudan University on the other hand, there appears to have been relatively little of this. ${ }^{15}$

The impact of all these changes on educational standards was enormous and provoked an early response from at least one courageous academic leader, Beida's Chancellor, Zhou Beiyuan, who published an article in 1972, probably with the support of Premier Zhou Enlai, urging higher standards and more attention to basic theory, and criticizing excessive practical work and the substitution of workshop labour for laboratory experiments. ${ }^{16}$ At Beida a short entrance examination which included Chinese, math, physics and chemistry, became part of the final stage of the admission process. In 1973 this "revisionist" trend accelerated and standardized exams were given that summer in many parts of the nation."

These and other moderating changes in some of China's best universities during 1973 constituted a retreat from the revolution in education in the eyes of radicals and provoked their own counterattack. ${ }^{18}$ The moderating trends were called the "hui-ch'ao" or "reverse current" and the radical reaction to them which began in August, 1973 was called the "going-against-the-tide"' campaign which later merged with the famous anti-Lin Biao, anti-Confucius campaign which heralded the Gang of Four's direct, if initially veiled, assult on Premier Zhou Enlai.

On August 10, 1973 the People's Daily published the soon-to-be famous letter of Chang Tiehsheng, a Liaoning province student who could not answer any of the questions on a college entrance exam. Chang submitted a blank paper accompanied by a letter arguing that it was unfair to send students to work in the countryside and then examine them as a condition of university admission. Chang's case brewed a national propaganda storm. The trend toward re-establishing the entrance exam as the basic means of evaluating students in the final university stage of the admission process was halted, although the use of exams was not entirely eliminated.

In early 1975 the first Minister of Education since the Cultural Revolution was appointed. Zhou Rungzin was openly critical of low standards and the lack of scientific research. The radicals with Chang Tiehsheng in the forefront attacked the Minister. Qinghua university administrators wrote Mao complaining of the low standards in university education, saying that some school graduates who entered university were "not even capable of reading a book". Mao gave the letter to a group of radical students at Qinghua and told them to struggle against the "right deviationist wind on the educational front."19 In many ways this was to be the final battle of the Cultural Revolution decade with the Gang of Four determined to destroy the political power of the by then terminnaly ill Premier, his recently rehabilitated protégé Deng Xiaoping and their moderate supporters. In February, 1976 Zhou Enlai died. In April, Deng Xiaoping was purged. It appeared as if the radicals might be within reach of victory or, at least, a strengthened position from which they could control areas like education. But within months Chairman Mao was dead and within 
weeks of his death in September, 1976 the Gang of Four was purged. A new coalition of veteran civilian and military leaders began to direct China along a course of economic development in which pragmatism, not politics, has been in command. In the past three years this leadership has dismantled dozens of Mao's policies. None have been so quickly or thoroughly reversed as those in the field of education.

\section{Education Since Mao: Primary \& Middle}

Changes in education policy and practices at the primary and middle school level came rapidly after Mao's death and the purge of the Gang of Four in the fall of 1976. The major thrust of the reforms was to raise the quality of education by emphasizing discipline, respect for teachers, and the importance of basic as distinct from applied and political knowledge. The desperate rush to elevate quality has led to far less local autonomy and variation in the regular school system as attempts have been made to unify standards, curricular, text books and the length of schooling. ${ }^{20}$ On this last point it appears that the question of extending the ten year school period is still being actively discussed and perhaps hotly debated. In the summer of 1977, Suzanne Pepper, an American specialist on Chinese education was told by Ministry officials that it would not be changed. ${ }^{21}$ Interviews I had with the Ministry in June, 1979 indicated that this question was under active review. Later a Chinese university official told me that the Ministry of Education has already made the decision to increase the length of schooling to eleven years by increasing the Senior Middle School period from two to three years thus providing a total of eleven years for pre-university education. ${ }^{22}$

Of critical importance in raising the level of educational quality has been the priority given to elevating the standards of teachers and providing them with better working conditions. Tens, perhaps hundreds of thousands, of China's more than ten million teachers, began to teach during the Cultural Revolution decade with no normal school training. A significant percentage of these were not Middle School graduates, and some had never even attended Middle School. Countless better qualified teachers were arbitrarily dismissed or transferred to other jobs. For example, in Shandong province alone 17,000 teachers left their posts for one reason or another during the Cultural Revolution decade. Throughout China there is now a drive to have these people returned to the class room. In the case of Shandong, 10,500 had returned by March, $1979 .{ }^{23}$

Ultimately the solution to the problem of teaching quality will be the increasing percentage of new teachers who are graduates of Normal Universities. In the meantime, teachers are being encouraged to upgrade themselves by part-time study in special programmes initiated by universities as well as correspondence, radio and television courses. It is difficult to acquire national statistics on the numbers involved in such programmes, but the limited data that is available from some provinces indicate the figures could be extremely high. For example, in the spring of 1979, 80,000 teachers were enrolled in a correspondence school for teachers in Shanxi province where courses were offered in math, physics, chemistry and Chinese. ${ }^{24}$ In Hunan province 160,000 primary as well as middle school teachers were reported to be engaged in part-time study through correspondence courses. ${ }^{25}$ If these figures are at all representative, they would suggest that well over 2.5 million primary, and middle school teachers are currently upgrading themselves through part-time correspondence courses. 
8 W.G. Saywell

Almost immediately after the downfall of the Gang of Four the government set about to improve the working conditions of China's teachers. In early 1977 they were guaranteed that five-sixth of their time could be devoted to academic work with a minimum of interference by other responsibilities such as political study and activity. The government has also forbidden other administrative units from interfering with the assignment of teachers. ${ }^{26}$ Revolutionary committees which ran the schools are being disbanded and replaced by the authority of principals and vice-principals working under the general policy supervision of party committees.

A more controversial scheme for raising standards is the reintroduction of the system of streaming which dates back to the early 1950's but was never used extensively. Students are streamed into fast and slow or fast, average and slow classes according to their examination marks. ${ }^{27}$ The system continues to be one of the most hotly debated areas of Chinese education, both on pedagogical and ideological grounds. In March, 1979, for instance, the Jilin Daily published a work study report entitled "Adopt measures to abolish slow classes" and included letters from their readers who argued that the disadvantages of the system far outweighed the assumed advantages.

Primary and middle school are where students receive a basic education. This is particularly true for primary schools. How can we judge a student to be a slow learner once and for all from the results of a single examination? Furthermore, with classes divided into two categories faster learners will make more rapid progress while slow ones will become even slower in study. As a result, teachers of slow learning classes lose confidence, students in such classes cannot hold their heads up and their parents feel ashamed. If this situation is allowed to go unchecked, how can it not affect the advancement of the quality of education. ${ }^{28}$

Officials admit it is controversial but claim that students are not locked into a stream and can be moved to another if their rate of progress changes.

The issue of streaming remained a major focal point of educational controversy throughout the summer of 1979. A major report by two New China News Agency (NCNA) reporters who had attended several educational conferences and visited many schools stressed that it was an extremely controversial practice, that the best teachers were assigned exclusively to "fast" classes, and that slower learners were being ignored and were losing confidence. The report went on:

Furthermore, some localities and schools are purely seeking a high percentage of graduates admitted to higher-level schools, and many secondary schools have turned their "fast progress" classes into "higher examination" classes... Certain people have also regarded the percentage of graduates admitted to higher level schools as the sole criterion for evaluating the operation of a school. 29

Various comments by high educational officials, including a July 17,1979 broadcast of remarks made earlier by Education Minister Jiang Nanxiang, argue that streaming has been made necessary by the severe damage done to educational quality by the Gang of Four and Lin Biao. The major thrust of these arguments is that it is a temporary expedient designed to quickly raise standards, and teachers must not ignore their responsibilities to the slower learners. ${ }^{30}$

Perhaps the most significant reversal of educational policy since Mao was the re- 


\section{Education in China since Mao}

introduction of the key school system at all levels from primary to university in the fall of 1977. Schools were designated "key" ones at all levels from district and county to municipality, province and nation. In January, 1978 there were twenty primary and middle schools designated as national key schools, directly responsible to the Ministry of Education in Peking. In June, 1979 Ministry officials told me that there were now over 1,000 key primary and middle schools run by other jurisdictions throughout the country. The spokesman indicated that the Ministry now felt this number might be excessive and was actively studying the possibility of reducing it. In Shanghai, Fudan University officials reported that the city's ten districts each had two or three key middle and primary schools, as did the city's ten suburban counties. Shanghai has two key middle schools directly responsible to the Ministry of Education and one each to Fudan University and the Shanghai Teachers University.

Admission to the key schools is exclusively by entrance examination. Those who do not receive a sufficiently high score at each level enter regular schools. I was told that the examination for entry to key primary schools is a predominantly oral test in which general levels of intelligence and knowledge are examined. Parents I spoke with said they taught their pre-school children some characters and basic math to prepare them for these tests.

While the key school system does not itself appear to be publicly debated, certain aspects of it are. In June, 1979, for example, the Jilin Daily attacked the practice of entrance exams for primary schools arguing that to select "only the brightest through testing. . .runs counter to the materialist theory of knowledge and is unreasonable." The newspaper also argued that students should not be allowed to go beyond the district in which they lived to enter a key school. ${ }^{31}$ Officials argue that the key school system is designed to do more than provide the highest standards of education to the best students. Key schools are regarded as centres of experimentation in curricula, teaching methods and materials which can serve as models for the regular school system. Both teachers and administrative officials from regular schools visit and observe what is happening at key schools. However valid this side of the key school structure may in fact be, it nevertheless injects an elitist orientation to the primary and middle school structure of China which is undoubtedly disputed within inner party circles, and remains vulnerable to the attack of a more radical leadership.

While the main emphasis in recent educational reforms has been on the elevation of quality, higher participation rates continue to be a major concern. In the summer of 1977 Suzanne Pepper was told by Ministry of Education officials that $95 \%$ of China's primary school age children, or 150 million students, attended school, a figure 6.2 times the pre1949 one. ${ }^{32}$ In the spring of 1978 the Clark Kerr study group was given the same figures. ${ }^{33}$ Ministry officials told me in June, 1979 that China's 940,000 primary schools enrolled a total of 140 million students. Later that month the state Statistical Bureau issued official statistics in a number of areas and reported that $7,870,000$ children attended kindergarten and $146,240,000$ went to primary school. ${ }^{34}$ While the discrepancies may be explained by a move toward more refined statistical analysis in China generally, and should not therefore be considered very important, it appears evident that improved success in lowering the birth rate in China's cities may also be a factor. Ministry and university officials as well as recent emigrés from major cities indicate that a number of primary schools have been closed because of the lowering birth rate in centres like Beijing, Shanghai, Tienjin and Guangzhou. 
At the secondary school level Pepper was informed that 123,000 regular junior and middle schools had a total enrollment of $58,280,000$ in 1977 . This was claimed to be 56 times the number prior to 1949 and 3.8 times the 1966 figure.$^{35}$ Clark Kerr's group was given a figure of $68,900,000$ million a year later. ${ }^{36}$ Officials told me the number was 65 million, a figure that later that month was only slightly refined by the report of the Statistical Bureau to a total of $65,480,000 \cdot{ }^{37}$ One possible explanation for the major discrepancy between the 1978 and 1979 figures comes from reports of emigrés in Hong Kong which indicate that in a number of locations the level of primary school graduates has been so low that a large number are not being allowed to continue immediately to junior middle school. Reports I heard in Hong Kong in July, 1979 indicated that in Guangzhou 20\% were being held back while in Hangzhou the reported figure was $40 \%$.

These figures do not include secondary technical school education the expansion of which is currently being given considerable emphasis. I was told that China had 2,760 such schools with a total enrollment of 880,000 . While Pepper had been given a figure of 799,000 students in the summer of 1977 the Statistical Bureau's report of June, 1979 indicated that the current enrollment of 880,000 was 200,000 more than in $1977 .^{38}$ These figures do not include an estimated 1,200 factory or enterprise-operated vocational schools supervised by the Labour Bureau under the State Council. In addition, there are $68,000,000$ Chinese enrolled in spare time primary and middle school programmes of all types. $^{39}$

It is extremely difficult to translate these statistics into percentage rates of attendance and generally accepted rates of literacy. Ministry officials now claim that primary school education is universal or has been "popularized" in all but the most remote areas. I was told that $95 \%$ of primary school age children attend school and that it is only in the remote areas that the drop out rate is at all significant. Since in China basic literacy is normally considered to be attained by primary school graduates, these figures would indicate that within several years China may come close to attaining near universal literacy for the under twenty-five age group. The qualification "basic" however should be stressed for in the rural areas where $80 \%$ of China's population live, drop out rates are higher, teaching standards lower, and the school week and school year shorter. ${ }^{40}$ Given these problems, it is very difficult to determine just what the level of a primary school graduate is.

Statistics for secondary school participation rates present even greater difficulties of interpretation. The Chinese target for 1985 is to make junior middle school education universal in rural areas and senior middle school education universal in urban areas. Ministry officials told me that in China's major cities senior middle school education was already universal. When I expressed some skepticism they indicated that not only did all attend senior middle school but that all graduated. My continued skepticism led only to the qualification that this was true only of the largest cities and did not include their suburbs. Since it is easier for the Chinese government to provide middle school education to China's urban youth than it is to give them jobs the general claim is probably true. As one Chinese spokesman said to me, "what else can they do?" No hard data appears to be available on current national statistics, but most interviewers felt that on a national basis well over $50 \%$ entered junior middle school, but considerably less than that went on to senior middle school. 


\section{Education Since Mao: Higher}

\section{The Key University System and Entrance Exams}

The reversal of policies in higher education since 1977, particularly the re-introduction of the key university system and nationally unified entrance exams, have essentially restored the system of pre-Cultural Revolution days. As of early June 1979 there were 89 key institutions of higher education. ${ }^{41}$ Twenty-six of these institutions are responsible directly to the national Ministry of Education. The others are responsible to a wide variety of other jurisdictions including the provincial governments, other national ministries and academies. For example, the Peking Medical Institute is directly under the Ministry of Health, while the Nanjing Engineering Institute is responsible directly to the Academy of Sciences.

The concentration of the best resources, professors, and students in key universities is justified not only on the basis of China's need to make up the lost ten years in quality education and research. It is also viewed as the best means of raising standards generally by means of experimentation, the training of future professors for other institutions and the model the key institutions provide. Officials at Shanghai's "key" Fudan university explained how university authorities and scholars from other institutions visit their campus to observe and adopt those ideas suitable to their own universities. The primary purpose of the key universities is to train research scholars and professors for other universities, academies and leading research institutes throughout the nation. This emphasis on quality education in key institutions has been reiterated in a number of ways. One recent example is the fact that several key universities appear to be readjusting earlier enrollment targets downward. At Beida for example, the original target for a total enrolment in 1985 of 20,000 students, is being studied and will, I was told by an official at that university, probably be lowered to between 15,000 and 18,000 .

While priority is given to quality at the key universities, in the nation's overall policy for higher education quantity is also being stressed. In 1973 only 400 institutions of higher education were in operation in China. In 1979 the number had jumped to 598 enrolling a total of 850,000 students. This figure was 230,000 higher than that for 1977 and compares with a total university enrollment in 1965 of $674,000 .^{42}$ With a population now officially estimated at $975,000,000$ this means that an extraordinarily tiny fraction of the population will receive a university education. The United States with one quarter China's population enrolls more than fifteen times as many university students, while Canada with a population of just over $2 \%$ that of China's enrolls about $50 \%$ as many university students "In order for 10 percent of the age cohort to be in higher education - a minimum level for a modernized industrial nation, will require at least a multiplication of the present system by 15 times over." 43 It is extremely unlikely, even if China's modernization drive is relatively successful, that the nation will come anywhere near achieving this by the end of the century.

While the Ministry of Education determines enrollment policy this is now done in close collaboration with other ministries, government divisions, and the universities. Decisions on 1978 enrollment, for instance, were settled at a national conference on higher education attended by representatives of China's universities. New universities are being opened and existing ones expanded. Nearly 200 new institutions of higher education were opened 
in $1978 .^{44}$ One report indicates a national target for 1985 of $3,200,000$ students at 1,500 institutions of higher learning. ${ }^{45}$ If comparative figures with the industrialized west on university enrollment are exceptionally low, absolute figures for China's overall educational system are extraordinary. Total student enrollment in primary, middle and postsecondary institutions has now reached 210 million students supported by 10 million teachers and educational workers. ${ }^{46}$ These figures, Ministry officials told me, do not include part-time study.

The most significant change in higher education since the Autumn of 1976 has been the reintroduction of the nationally unified college entrance examinations, first held in December 1977 for the 1978 spring semester. These are now considered a "permanent" feature of the system. In 1977 the examinations were written and administered on a provincial basis. In 1978 they were nationally unified and set by the Ministry of Education. ${ }^{47}$ Exams are currently set by a committee of university scholars established by the Ministry and are administered and marked by enrollment committees of similar composition at different administrative levels.

Today, students may attempt the exams any number of times until they are twentyfive years of age. In 1977, and to a lesser extent in 1978, exceptions to this age limit allowed students up to 30 to attempt the exams, thereby providing some opportunity for university education to a fraction of those who were denied it by the Cultural Revolution. The age limit for exceptions, of which there will be extremely few in 1979, was lowered to $28 .^{48}$ Both Ministry and university officials indicated to me that the age limit will likely soon drop to 23 as more and more students enter university directly from middle school.

Increased enrollment in China's middle schools as well as some opportunity for rusticated youth to try the exams has made competition fierce. In 1977, 5.7 million students attempted the college entrance exams of whom 278,000 were eventually enrolled. The initial target had been 218,000 , but a conference on education held in the spring of 1978 decided to establish an additional 55 regular institutions of higher education including 13 which had been abolished or merged in 1971. As a result of these decisions an additional 60,000 students could be immediately accommodated. ${ }^{49}$

In 1978,6.9 million candidates sat for the exams of whom 300,000 were initially enrolled. Later an additional 100,000 were registered in several "affiliated" or "branch" universities associated with a few of China's major universities. Beida, for example, enrolled an additional 800 students. The "affiliated" organizations appear to use regular university faculty on a rotating basis. The students do not live on campus as all others do, but are commuters who take classes in different locations. Some instruction is by television and radio. In July, 1979, 4.7 million candidates attempted the three-day exams for an estimated 270,000 to 300,000 freshmen places. ${ }^{50}$ A Ministry of Education official explained that the number dropped in 1979 because of increased educational opportunities for China's middle school graduates in vocational, technical and spare-time educational programmes, as well as an improvement in opportunities for urban employment. ${ }^{51}$ The number also dropped because of the lowered age limit and the fewer rusticated youth thereby allowed to attempt the exams.

Candidates do not have to be middle school graduates although as China's educational system returns to normal an increasing percentage are. In 1977 only $30 \%$ of the freshman class entered university directly from middle school. What percentage of the remaining, who were largely rusticated youth, were nevertheless earlier graduates of middle school is 
not known. In 1978 these figures were exactly reversed. In July 1979, 67\% of those who sat the exams were middle school graduates. ${ }^{52}$ University officials told me these figures would rise dramatically in the next few years.

Students write a set of either liberal arts or science exams. In $197937 \%$ of the candidates wrote the arts exams and $67 \%$ the science set. Liberal arts students are examined on politics, Chinese, mathematics, history, geography and a foreign language. The science set includes exams on politics, Chinese, a foreign language, math, and adds physics and chemistry. In 1977 there was no foreign language exam. It was introduced in 1978 but at that time given no weight and only used as a "reference indicator". In 1979 the foreign language exam mark will be given a weight of $10 \%$ that of each of the others, (which themselves have equal weightings) for those students wishing to enter a key university. It is. expected that this will be raised each year until the foreign. language exam for entrance to key universities soon has an equal weighting with the other subjects. For entrance to regular universities the foreign language exam will remain only a reference point until foreign language study becomes more advanced throughout the nation's middle school system..$^{53}$ Foreign language study, particularly English and Japanese, is being given exceptional priority throughout the educational system, but as in other areas it will be some years before the full damage of the Cultural Revolution decade can be repaired.

While most informants described the exams as "not very difficult" or "rather easy", they do establish a minimum standard for college entrance. (See Appendix B for a completed copy of the 1979 English language exam). Normally marked out of a total score of 500, some of the top universities such as Beida, Qinghua and Fudan indicated that most of their freshman class in 1978 scored around the 400 level. This varied from department to department with normally higher scores being required in math and physics. Students who excel in particular subjects can be admitted to key universities with a somewhat lower average mark. Those who do not attain these high standards can be enrolled in the key universities' "affiliated" operations, regular universities or radio and television correspondence universities. ${ }^{54}$ Candidates for medical colleges take the regular science examination. Enrollment committees at the key universities select from lists of candidates perhaps 25 to $30 \%$ greater than the number of places they have available. Students can list 10 universities and two disciplines in each as their choice, for a total combination of 20 possible assignments. Of these ten, five may be key universities. ${ }^{55}$

The entrance exam is not the only criterion for university admission, but it is by far the most important. Students must also prove they are medically fit and of acceptable political background. All who attain the minimum mark in the entrance exam must undergo a physical examination. Extremely few handicapped students attend any of China's regular or key institutions of higher education. The political criterion is no longer one of class background. Today, it appears to be little more than a character reference, albeit a detailed and documented one, from the candidate's middle school and/or work unit. Since intellectuals are now considered "labouring people" their children are admitted to university as members of the working class, or if they have come from a period of time in the countryside, as peasants.

The political report that accompanies a student's marks in the dossier sent to university enrollment committees is, in fact, the summary of a political or moral assessment that is begun at the primary school level. In primary schools, reports on every student's behaviour are written regularly throughout each school year and must be read, signed and returned 
by the parents. The reports emphasize the student's attitude towards study, labour, classmates and teachers. At the end of primary school a summary of these goes with the student to his/her middle school. At that level the same procedure is followed with a final summary being sent to the universities. ${ }^{56}$ While one's conduct at middle school can prevent a brilliant student from entering university, his or her middle school academic record is not taken into consideration at all. The student's academic ability is judged exclusively by the college entrance exam. Officials indicated to me that this might change later when China's pre-university educational system is fully restored and standards elevated. The disruption of the Cultural Revolution decade was so severe that in the official view, middle school marks at this time might mean very little, if anything.

There remain persistent reports from returning overseas Chinese visitors, foreign experts teaching in China and others that "guanxi", or "connections", so important throughout Chinese history, still play an important role in most areas of Chinese life from getting favored overseas diplomatic postings to being included in educational and technical delegations going abroad. In higher education the college entrance exam has undoubtedly decreased the value of "guanxi" or entering by "the back door". Those who mark the exams do not see the candidate's name and in the few celebrated cases where favouritism has been exercised and discovered the incidents have evoked nation-wide attention. Perhaps the most celebrated case was that of Wang Xiaping who entered Beida's department of law in 1977, only to be expelled later when it was discovered that his father, a high Shanxi provincial party authority, ordered an invigilator to arrange for answered papers to be smuggled into the local examination hall.

By the spring of 1980 the last of China's pre-entrance exam or 'worker-peasant' soldier' classes will have graduated. At that point virtually all entering students will be middle school graduates, most of them coming directly from secondary institutions to universities. Chosen on a fiercely competitive national exam system the quality of the student body should be far superior to that of the early 1970's. Some observers, however, would question the degree to which there is any significant difference in the class background of the two groups of students, arguing that essentially the same students went to university but with the difference that their educational development was interrupted by at least two years of labor. When I suggested that this was the case to university officials and professors in June 1979, they insisted it was not so. As one irate professor, whom I perhaps pushed a little far on the point, responded, "No that is simply not so. My god we should know, we had to teach them!" Even if a significant number of the earlier workerpeasant students were in fact "recycled" youth from privileged urban groups, the disruption in their educational backgrounds made many ill-prepared for a university education. As China enters the 1980's the effects of these disruptions on China's university students are diminishing rapidly and the nation's university teachers are ecstatic about being allowed to teach, with little political disruption, a body of competitively chosen, bright, well motivated students.

\section{Curriculum}

One of the first reforms implemented after the fall of the Gang of Four was the lengthening of the three year university programme back to four years. Initially all programmes were lengthened to four years but early exceptions to allow five year programmes were 
given to some universities for medicine, archeology and some foreign languages. The general policy is currently under review and some institutions such as Qinghua have applied, and it appears will receive approval, for five year science and engineering programmes. Beida officials told me that this was also being discussed, but with the exception of the foreign language departments, the majority of faculty favoured the retention of a four year system for both arts and science. Fudan indicated that the discussion there seemed to be arriving at a concensus of four years in arts and five in science.

All institutions are now placing a very major emphasis on foreign language study. Most foreign language institutes now have teachers hired from abroad and by the fall of 1979 this will likely also be true of foreign language departments in China's leading universities. All students in Chinese universities are required to study at least one foreign language. At the post-graduate level at Qinghua and presumably in the science and applied science fields of other institutions, two foreign languages are required.

The earlier requirement that faculty and students spend a significant amount of time in manual labour has been diluted to the point of virtual extinction. Universities maintain workshops and factories on their campuses, but neither faculty nor students spend time in them. While estimates of the length of time students spend in labour varied slightly from place to place (four to eight weeks) the usual answer I was given was that they were expected to spend a total of four or five weeks in labour at some point before they graduated. This might take the form of a week or so each year, or as reported for one university, all four weeks at the outset of the university programme "to get it over"! At the faculty level physical labour is at best an occasional and not very strenuous ritual. Some told me they no longer did any, while others chuckled that they had "picked castor beans once", and others that they occasionally "helped sweep up"! Qinghua authorities indicated that faculty over the age of 50 were entirely exempt.

Political study for students now appears to be exclusively covered by the regular political science course which emphasizes Marxist theory and the history of the Chinese Communist Party. Faculty still engage in regular political study sessions. At Quinghua I was told these occupied one or two afternoons each week, while at Fudan one afternoon a week is the usual routine. My Fudan hosts explained that these sessions covered political events abroad as well as within China, that they usually studied documents such as party and state reports, the speeches of leaders, and newspaper editorials. These were discussed in small groups of twenty or thirty faculty members. On other occasions the entire faculty meets in the University auditorium to listen to a major political address.

Instruction and research in most of the pre-Cultural Revolution subjects appear to have been resumed. Thus for example, Beida has resumed classes within its Philosophy department on major world religions. Psychology, which was damned and outlawed as a "sham" by the Gang of Four, has been rehabilitated as a "science" and those purged in the earlier "criticize psychology" movement have been fully rehabilitated. ${ }^{57}$ Entirely new departments are being established in areas particularly relevant to China's modernization drive. For example, twelve colleges and universities in Shanghai have formulated plans to establish departments to teach administration. ${ }^{58}$ China has even established a "Tourism University" in Shanghai to train managerial cadres in a two year course that includes foreign language, hotel service, economics, geography and computer technology. Admission is only possible through the national unified college entrance exams. ${ }^{59}$

Another change that may come in the near future is a move toward interdisciplinary 
studies. In February 1979 the President of the Shanghai Number 1 Medical College urged this, indicating that China needs comprehensive universities that will incorporate the study of medicine, science and engineering. He blamed the lack of interdisciplinary studies on China's original adoption of the Soviet model in higher education. ${ }^{60}$ At the present time the medical sciences are taught entirely in separate institutions. This presents obvious problems in the area of basic science training in the medical universities. It also inhibits other new departures. My hosts at Sichuan Medical College, for example, were extremely interested in learning about the University of Toronto's Department of Bio-Medical Engineering, an interdisciplinary division supported by both the medical and engineering faculties. Under the present organizational structure of Chinese universities this kind of co-operative interdisciplinary venture would be impossible within one institution.

\section{The Degree System and Graduate Studies}

Chinese universities do not confer degrees in the traditional western sense. However, they are currently studying the introduction of degrees and their motivation for doing so might well be their recognition that such a system would facilitate placing their graduates in foreign universities. A Beida official explained that some faculty there favoured the introduction of a degree system of four years for the B.A., two for an M.A. and four for a $\mathrm{Ph}$.D. University officials generally seemed to think approval would soon be forthcoming for some such system. An article in the May 27, 1979 issue of the Guangming Daily supported the restoration of academic degrees and suggested criteria for the evaluation of doctoral work including the defence of the dissertation. ${ }^{61}$

Literally a decade passed without China's universities being involved in graduate education in any systematic way or to any significant degree. As some of the nation's universities graduated their first post-Cultural Revolution students in 1973, they prepared to accept very limited numbers of these graduates into advanced study in 1973 or 1974. Beida, for example, indicated to me in a visit to that campus in the spring of 1973 , that they were hoping to enroll about 150 science and 100 Arts graduates that Fall. But those who attended graduate programmes were sharply criticized by radicals for pursuing an elitist and individualistic road, and while some graduate work did go on during the Gang of Four era, it received little official encouragement and was limited in both scope and quality. Shortly after the death of Mao and the purge of the Gang of Four, Ministry and university officials began to discuss plans for the full restoration of graduate programmes.

In November 1977, the Ministry of Education and the Academy of Sciences issued a joint notice containing instructions for the admission of graduate students. These included the restoration of an entrance exam. In some fields national graduate entrance exams were held in the early 1950's, but none were given after the Great Leap Forward later in that decade. While no indication was given in the Fall of 1977 as to how many graduate students should be enrolled, it was announced that 200 institutions of higher education as well as research institutes of the Academy of Science and various government departments would accept graduate students in the Fall of 1978. An NCNA report of March 1979 stated that over 200 institutions of higher education and more than 100 scientific research institutes had been approved to accept research students. These included all the research institutes affiliated with both the Chinese Academy of Science and the Chinese Academy of Social Sciences. Also approved were a wide variety of scientific research organizations and offices under various central governmental ministries, and a few of the better qualified 
ones under the jurisdiction of provinces, municipalities, autonomous regions, and the armed forces.

The same report indicated that entrance exams would include tests on political ideology, foreign language, "basic knowledge" and basic professional topics.

\begin{abstract}
The political ideology test aims to find out to what degree a candidate has mastered basic Marxist-Leninist theories. It will test how a candidate has mastered basic principles of philosophy, political economics, scientific socialism and the basic theory of the CCP in leading China's revolution and construction; how a candidate has understood the guidelines of the third plenum of the 11 th CCP Central Committee, and how a candidate has criticized the various fallacies of Lin Biao and the gang of four in tampering with Marxism-Lenimsim-Mao-Zedong thought.
\end{abstract}

The report also stated that students must prove that they have a knowledge of grammar and have attained a certain level of ability in translation of one foreign language. ${ }^{62}$

In the 1978-79 academic year China's universities had a total graduate student enrollment of 8,000 students. $^{63}$ In the spring of 1979 China's best known science and engineering university, Qinghua, had only 350 graduate students, but it was planning for an estimated total of 3,000 in a few years time. The situation at Beida was similar with a spring 1979 enrollment of 460 graduate students. Fudan admitted a few graduate students in 1977 , but only formally resumed their graduate admissions in 1978. By the spring of 1979 they had a total of only 300 graduate students. The Sichuan Medical College was planning to admit graduates in September $1979 .{ }^{64}$ In June 1979 over 2,400 candidates sat the entrance exams for post-graduate courses in Peking's universities and research institutes. ${ }^{65}$ It will obviously take several years to restore fully graduate education in the People's Republic of China. The consequences for a nation of almost one billion people desperately struggling to modernize against immense social and economic problems, of virtually going without serious graduate education for a decade are almost beyond comprehension.

\title{
University Administration and Working Conditions
}

Until recently, Chinese universities, like other areas of post-Cultural Revolution China, have been run by revolutionary committees. While representation on these varied from campus to campus, they usually included representatives of the Workers Propaganda teams and PLA units which had re-established order in the universities as they re-opened in the early 1970's. The committees normally also included representatives of the veteran cadres, workers, professors and students. For example, the Qinghua revolutionary committee in the spring of 1973 , consisted of six teachers, six staff workers, five cadres, five students, four workers propaganda team members, four representatives of the PLA, and one dependant of a staff member.

Since the downfall of the Gang of Four the workers propaganda teams have been withdrawn and the revolutionary committees are being replaced by a dual authority structure in which the traditional academic/administrative leadership of the universities is overseen by the ultimate policy authority of the party committee. Under the revolutionary committee structure, universities and research institutes were often led and administered by personnel who had little if any background directly related to the institutions they ran. Today the daily administration of Chinese universities is in the 
hands of a President or Chancellor and a number of vice-presidents or vice-chancellors each with a responsibility for a functional division of the University's affairs, not dissimilar to such divisions of major Western institutions. Qinghua for example has six vicepresidents, while Beida has eight. In many cases the most senior academic/administrative leaders will also be party members and sit on the party committee which sets the overall policy for the institution and ensures that it follows national party policies.

Chinese universities and research institutes have not moved back to their traditional duality of academic/party leadership without facing serious problems, many of which will take years to overcome fully. At some institutions, cadres who know little about education have retained too much authority, while at others there has been a growing concern that scientists are too often distracted from their research and teaching by being given heavy administrative burdens. One of the most interesting examples of difficulties encountered in returning to pre-Cultural Revolution norms of academic leadership was provided by Shandong University where an enlarged meeting of its academic committee held in early 1979 and presided over by the University President,

expressed the hope that the secretary of the party committee and the president of the university would take the lead in emancipating their minds, assume responsibility and take measures to encourage cadres to learn professional work in order to acquaint themselves with the work of an institute of higher learning and to handle matters in accordance with the principles of education.

The president and party secretary "accepted the responsibility for the criticisms by academic committee members and made self-criticism." ${ }^{66}$ In February 1979 the Peking Municipal Science and Technology Committee held a working conference of all the research institutes in the capital. Participants urged the party to discontinue its role in daily administration. "Leadership over professional and administrative affairs should be entirely delegated to the director and deputy director." This would leave the party free to exercise its leadership in the policy area and allow the professionals to get on which the task of running the institution. ${ }^{67}$

If recent changes in the administration of Chinese universities have reinforced the traditional role of academic administrators, this has been at the expense of students as well as cadre participation in university policy making. It is difficult to judge the real influence exercised by student representatives on former revolutionary committees of Chinese universities. Their numbers varied considerably. For example, in 1973 five of Qinghua's thirty-one revolutionary committee members were students, while at Beida that year the figure was seven of thirty-nine and at Jungshan University in Guangzhou it was only two of thirty-two. ${ }^{68}$ With the return of pre-Cultural Revolution authority structures, the role of student leadership has moved into the more traditional areas of extra-curricular activities. Elected student unions or associations were sufficiently well organized by the spring of 1979 to hold the 19th Congress of All-China Students Federation, which defined their main function as providing a link between the student masses, the Party committee and the school's Communist Youth League organization (CYL). While CYL members on campus might continue to exert some influence on policy through their links with the party committee, student associations as such wield little if any direct influence on university policy or its implementation. As Shanghai radio reported in the spring of 1979 , "Some students erroneously believed that, in bringing democracy 
into play, it is necessary to have student self-government. Such a trend has now been eliminated through ideological education." 69 It is ironic that the "student power movement" in western universities gained some of its inspiration from the power China's youth temporarily exerted during the Cultural Revolution, when today the role of China's university students in the affairs of their institutions appears to be virtually non-existent, and certainly less significant than in most major North American universities.

All of these changes are undoubtedly welcomed by the faculty of China's universities. With relatively little time being required for political study and virtually none in manual labour, China's professors are getting back to the task of teaching and doing research. They have seen the return of good students to their classrooms, are enjoying the return of full access to the foreign literature in their fields and the resumption of direct contact with foreign scholars. China's professors are also beginning to enjoy improved living conditions and are looking forward to possible salary increases. With only a very few exceptions in 1963 , no Chinese professor has had a salary increase or promotion since 1956. Current university salaries range from about 53 to around $350 \mathrm{RMB}$, or approximately Cnd. $\$ 40$ to $\$ 250$. Now the salary and rank system is under active review and changes are imminent. Teaching loads appear to be similar to those in most North American institutions, with the average Chinese professor teaching from six to eight hours a week. But student/staff ratios averaging about 3 to 1 are ridiculously low by most western standards. Even when the targeted enrollment is reached they will be a very attractive ratio of about 4 to 1 .

A major problem facing China's universities is the large number of underqualified, and often totally unqualified teachers who were brought into the system during the Cultural Revolution decade. Western visitors have been told with remarkable candour that these people represent a major embarrassment. While most are not now teaching, they cannot be summarily dismissed. Some are being assigned teaching positions at the primary and middle school level, while still others are receiving new assignments on campus which do not involve instruction or research.

\section{International Educational Exchange}

In the early 1970's China negotiated a very limited number of student exchange agreements with western nations. A Canadian-Chinese agreement, for example, was signed in 1973 which included the principle of reciprocity. Since the autumn of that year there have always been at least twenty exchange students in each country and in recent years, the Chinese have more than doubled the number studying in Canadian universities. Until 1977 all Chinese under the agreement in Canada were language students. Since then a few in science and engineering have come. The Chinese government also slowly resumed its programme of hiring foreign language teachers, but here too the number remained very restricted until after the fall of the Gang of Four. While only a very few Chinese professors were sent abroad until the post-Mao period, and then normally for only very short visits, the number of educational, scientific and technological delegations that travelled to the West and Japan for periods of from three to eight weeks was far more significant.

In 1978 the Chinese made it known that they intended to send thousands of advanced students, teachers and researchers abroad, particularly in the areas of pure and applied science, engineering, technology and medicine. Canada was initially slated to be sent 500 but in June, 1979, a bilateral Canadian-Chinese agreement was signed allowing for approximately 100 Chinese "scholars" (i.e. Chinese not registered in degree programmes) to 
attend Canadian universities. Thousands of other Chinese scholars are going to Japan, the United States and European nations. The Chinese being sent under these programmes are predominantly in their late 30's or early 40's and are therefore people who completed their university education before the Cultural Revolution, but then experienced the complete disruption of their early years of teaching and research by that political upheaval. For the better part of a decade most of them were without access to their laboratories, libraries or any significant contact with international advances in their fields. The major purpose of their usual two year study periods abroad is to make up for those lost years by updating themselves in terms of western scientific knowledge, methodology and the use of advanced equipment and techniques.

\section{Part-time Education}

Since at least the early 1940's the Chinese Communists have developed a wide range of spare time, part-work/part-study, special technical, vocational and other educational programmes that collectively are often referred to as 'irregular education'. Perhaps the best known and most successful of these has been the training of 'barefoot doctors' and other paramedical workers. But other programmes in technical and vocational education for peasants and workers, normally on a part-time basis, have also flourished. These are continuing to receive some priority, particularly now as an alternative to the regular universities for those students who do not pass the college entrance exams and are assigned jobs in the nation's factories.

In the summer of 1977 the educational programmes in Chinese factories, known as July 21 st colleges, had a total enrollment of 780,000 students, while agricultural colleges enrolled about one million. In addition there were technical secondary schools in every branch of industry run by the central ministry concerned. At that time China was also aiming at establishing a secondary school for the mechanization of agriculture in every prefecture of the country, as "agricultural mechanization alone requires two million technicians trained to the secondary school level or above." 70

The part time educational facilities associated with factories provide their younger workers with basic education in math and sciences as well as the technical subjects associated with the factory's own area of production. They also usually provide foreign language instruction. Since practice varies greatly and no comprehensive statistics are available for programmes of this nature a few illustrations from information available in the spring of 1979 will have to provide at least a sense of the enormity and importance of this kind of education.

It was estimated for example that $19 \%$ of Peking's industrial workers were taking parttime courses at 4,500 factory-run sparetime classes. In Peking's Capital Iron and Steel company 14,000 workers were taking courses in math, physics, chemistry, foreign languages, as well as in metallurgy technology. In the next five years the company will increase by 2.5 times, the number of its workers and staff with a college level technical education. ${ }^{71}$ In the industrial city of Taiyuan, 60,000 workers in seventy large factories and mines were enrolled in spare-time classes, while at the Shengli oilfield in Shandong province 40,000 attended classes, of whom $10 \%$ were studying English, French, Japanese or German. ${ }^{72}$ A spare-time foreign language institute has been established in Shanghai which provides a two-year course in English, French, German and Japanese to scientists 


\section{Education in China since Mao}

and technicians who upon graduation are expected to be able to read a foreign language well enough to translate foreign technical literature. ${ }^{73}$

Reports from Shandong indicate that as part of a national plan the province hopes to educate all its workers under the age of 35 to at least a middle school or technical secondary school level within three to five years. In the spring of 1979 a reported 300,000 workers in that province were attending part-time classes. Part-time schools and universities are not limited to factories. In Peking the Peking Municipal Trade Union Council gives courses to workers. In 1978, 7,800 of the 11,000 enrolled graduated from courses that ranged from three months to three years. Enrollment was only by entrance exam and courses included such subjects as mechanical drawing, hydraulic machinery, electronics, English and Japanese. ${ }^{74}$ In Guangzhou the trade union organizations sponsored 103 spare-time schools in which 41,000 workers and staff participated in short-term training courses. ${ }^{75}$

The importance of upgrading technical educational facilities in rural China has been stressed by China's leaders at national conferences and in major political reports. In March, 1979, the All-China Scientific and Technological Association met in Shandong to discuss part-time scientific and technical education in rural areas. In urging the national promotion of this kind of education which is designed to provide part-time educational facilities to raise the level of their students to that of a secondary school technical education, the report indicated that under the Gang of Four "Some localities had farming machines but no one to operate them, insecticides but no one who knew how to use them and chemical fertilizers but no one who knew how to apply them. ${ }^{76}$ In the Yimeng area of that province alone, according to a February, $1979, N C N A$ report, there were more than 3,000 part-time science schools with 60,000 students all selected by examination. Courses normally of three to four years were offered in farm techniques, engineering, horticulture, and veterinary science as well as basic math, physics, chemistry, zoology and botany. Students were selected from junior and senior middle school graduates, production brigade and team leaders, and veteran peasants, while teachers were recruited from local peasants, qualified high school graduates and experienced technicians. ${ }^{77}$

\section{Conclusion}

China's new education policies face a number of difficulties and involve a great many short and long term political risks. In many areas the new policies are not being implemented as quickly or as thoroughly as possible. Given the extraordinary shift in education policies it is not surprising that problems in implementation are being experienced. Middle level cadres responsible for local and regional policy implementation are reluctant to move quickly or take any initiative that may leave them vulnerable to criticism should those policies shift quickly again because of political change at the top. That particular characteristic combined with the general inertia of any bureaucracy the size of China's, has always been a major obstacle to fundamental and comprehensive policy change. Provincial radio broadcasts in recent months have provided many examples of concern in this area. Zhejiang for instance reported that "At present the important thing is that some leading departments and comrades are still taking a passive wait-and-see attitude." 78 Another report urged cadres to be more daring in rehabilitating educational leaders who had been purged and hiring those who had been in political trouble. ${ }^{79}$ 
The extreme competitiveness of the entrance examination system at all levels involves educational as well as social and political risks. ${ }^{80}$ A system increasingly geared to nationally unified examinations runs the risk, known well in other parts of the world, of parents, students and teachers ignoring educational quality and concentrating only on those subjects, themes and problems perceived to be most relevant to the next set of exams. Educators admitted that this was a serious risk, and that the syndrome of 'why study that, it won't be on the exam. has already appeared. A People's Daily editorial in May, 1979, reminded middle schools that the majority of students do not go on to university and therefore the schools should not just concentrate on the college entrance exams.

Since the death of Mao, China's pragmatic leaders headed by Vice-Premier Deng Xiaoping, have designed a strategy for the most rapid and comprehensive modernization of the nation possible. This strategy incorporates major policy shifts and reversals in every area, which collectively pose the risk of subverting Chinese socialist, or perhaps more accurately, Maoist values. It is modernization, not westernization that is sought by China's present leadership just as it has been by China's reformers and revolutionaries since the early nineteenth century. Philosophical, ideological and pragmatic means of ensuring this distinction have been at the heart of China's great political debates on modernization since at least the 1870's. Today concern about this issue is particularly apparent in discussions on education policy. In the spring of 1979 in a meeting at Qinghua University, Minister of Education, Jiang Nanxiang warned that foreign imports in education were not like imported factory equipment and technology which "do not have a class character." The Minister continued that in education China must learn from the west, but obviously it does not meet with actual conditions in China to run education on models from capitalist countries or even to invite foreigners to run Chinese schools." ${ }^{21}$ Increasingly frequent calls for more attention to the leadership of the party in China's universities and in particular for greater attention to political and ideological work, indicate not only a recognition of problems but also provides evidence of the degree to which education policy remains sensitive to ideological debate within party circles. ${ }^{82}$

The leadership is even more concerned about the level of ideological work required amongst those youth who will not get into a university, particularly those who wish to, but fail the entrance exams. A predominant theme in reports on Communist Youth League activities has been the concern with raising the ideological level of youth so that not all will want to go to university and so that those who do but fail to get there will recognize the equal value of other futures. A major People's Daily editorial on May 17, 1979 , stressed the fact that it would be impossible for the state to spend more on education until the economy developed, and therefore there would be countless youth disappointed at not getting into university. These young people and their parents must be educated, the editorial stressed to:

consider the overall situation, relegate personal interests to the interests of the State and local interests to overall interests and understand the difficulties of the State and schools. . . It is all the more necessary to do meticulous ideological work among the large number of young people who fail the entrance examinations.

There were other ways to contribute, China's national paper argued,

Those who take the road of self-study and part-time study can scale the peaks of science and technology just the same. . Schools and parents should encourage 
young people to obey the State's assignments and go where the motherland needs them most. ${ }^{83}$

The same exhortation has been used over and over again in the provincial press and by major national leaders.

The answer to the problems of a frustrated youth, only a small fraction of whom can be absorbed into China's higher educational system, does not lie in ideological exhortation. It will only be found in general economic progress which will permit urban youth to remain in the cities, receive a good technical education and jobs consistent with that educational background. Since the Cultural Revolution 17 million Chinese youth have been sent to the countryside. Statistics vary on how many remain there. In the summar of 1977 a Ministry of Education official said there were still eight million young people with either a junior or senior middle school education from the cities working in the countryside, and that four million have returned to urban jobs. They also suggested that "Henceforth, we are planning for five million senior middle school graduates to go to the countryside each year." 84 I was told in the summer of 1979 that the policy of sending youth to the countryside would continue but that the numbers involved would be drastically reduced and the system much improved for the youth who go. If China's general modernization drive succeeds and urban population growth declines, the programme will eventually be abandoned. Although frequently justified in ideological terms the scheme has in fact been primarily motivated by economic necessity. Ministry officials told me that because of the decline in population growth in Shanghai, no youth from that city were sent to the countryside in 1978. A major problem at this time is the number of young people who have returned to the cities, illegally, or for Spring Festival and are refusing to go back to the countryside despite the fact they have no jobs, no income and no ration coupons, and thus represent a serious financial problem for their families. In the spring of 1979 , Chinese papers and radio broadcasts were full of appeals from various party, state and provincial sources to these youth to return to the countryside and assist in the spring harvest. Most reports were candid in admitting that the exhortations were far from successful. ${ }^{85}$

China's education and youth policies continue to face the dangers of a large number of frustrated and disenchanted young people. Millions of intelligent and talented young people had no opportunity at all to develop their academic or vocational potential during the period 1966 to 1976 . Millions have been permanently settled in the countryside. Others work in factory jobs that will always be frustrating to them. Until a combination of a decline in population growth and a steady rate of economic development occurs, the modest expansion available in China's educational system will continue to mean that there will be millions of young people unable to get the education they want. There will also be unemployed and underemployed youth in the cities and possibly large numbers of dis. enchanted and potentially angry youth forcibly sent to the countryside.

The youth of the Cultural Revolution decade whose education was aborted or hopelessly disrupted represent a lost generation of disillusioned and often embittered citizens who will be professionally active for another third of a century. If the revolution of rising expectations now being unleashed by the modernization drive, and changes in China's education policies cannot be reasonably fulfilling for most of the nation's youth, the "lost generation" will be continually reinforced with significant numbers of disillusioned 
young people. This may very well be one of the most explosive problems facing China's leadership in the 1980's.

If, on the one hand, the political leadership and ideological direction of the country generally should change sharply, these changes will be reflected quickly and profoundly in education which has consistently been one of the areas most sensitive to ideological debate and policy change. If, on the other hand, China's drive toward modernization has reasonable success and as both cause and effect of that, the type of pragmatic and ideologically moderate leadership now in control lasts, the changes in China's education policies introduced since Mao will have a profound impact on China's overall course in the foreseeable future.

Several features of current policies in education, in particular the key school system and the despatch abroad of thousands of students and scholars, cannot help but create a new generation of elites, less committed to the essentially egalitarian ethic of the earlier Maoist revolution. There could be a striking historical parallel here with the first decade of this century, when in a desperate move to retain power by reform, the Qing dynasty set up modern schools and sent thousands of Chinese students to study abroad, particularly in Japan. These young people became the recruits and leaders of the revolutionary forces that then overthrew the dynasty and established a republic. They also became the leaders of the Marxist revolution who ultimately led the Chinese Communist Party to power. Only Mao Zedong among the very top leaders did not share that foreign experience.

It would be foolhardy to predict that the new educational system, if it continues, will produce a generation intent upon overthrowing the basic form of government and society China has evolved since 1949. But one would be equally foolish to ignore the probability that if current policies continue they could produce a generation insistent that there be no return to the kinds of Maoist policies now being jettisoned. That the Chinese already recognize this is abundantly clear. That the leadership is at this point either willing or capable of doing anything about it, is not. Those interested in the overall political and economic course China will follow, should keep their eyes rivetted to the area of education. It provides the lithmus test to the true ideological underpinnings beneath the political rhetoric in other major policy areas and an extraordinarily sensitive weathervane to policy changes in the wind.

\section{FOOTNOTES}

1. Suzanne Pepper, "Education and Revolution: The 'Chinese Model' Revised", Asian Survey, September, 1978, Vol. XVIII, No. 9 provides the first two figures. For the figure 440,000 see Joel Glassman, "Change and Continuity in Chinese Communist Education Policy: 'Two-Line Struggle' Versus Incremental Trends", Contemporary China, Vol. 2, No. 2, Summer 1978. p. 60.

Much of the background material in this article relies heavily on Ms. Pepper's excellent article in Asian Survey. I am also indebted to her for the advice and assistance she gave me in Hong Kong in the Spring of 1979.

2. Leo A. Orleans, Professional Manpower and Education in Communist China, Washington, National Science Foundation, 1960. p. 111.

3. Glassman, op. cit., p. 60.

4. Pepper, op. cit., (1978), p. 850.

5. Glassman, op. cit., p. 60 . 


\section{Education in China since Mao}

6. Renmin Ribao (People's Daily), May 17, 1979, British Broadcasting Corporation, Summary of World Broadcasts, Part III. The Far East, (hereafter FE) 6122/BII/7-10.

7. The Chinese term 'jungdian' is variously translated as "key" or "key point". Chinese invariably used the term key in my discussions with them in 1979.

8. Renmin Ribao, July $22,1968$.

9. The revolutionary committees usually had about thirty-odd members consisting of teachers, staff workers, cadres, students, representatives of the workers propaganda team, the PLA unit and dependents of university staff. For example in 1973 I visited Qinghua university and was informed by officials there that the revolutionary committee had 31 members with the following number of representatives from the above groups: $6 ; 6 ; 5 ; 4 ; 4 ; 1$.

Army representatives left most Chinese universities after Lin Biao's attempted coup in 1971. Not all representatives of the workers propaganda teams left until the winter of $1977 / 78$.

10. Pepper op. cit., (1978) p. 858.

11. In an interesting article written shortly after the downfall of the Gang of Four, Michael Luk suggests that there were three major principles upon which Chinese policy on higher education was based during the Cultural Revolution decade. He identifies these as: putting proletarian politics in command; combining theory and practice; combining education with production. With each principle he identifies several specific policies. In her response to the paper first presented at a conference at the University of Hong Kong, Suzanne Pepper adds a fourth which she called "for want of a better term, ...the sociological aspect of the education revolution, which aimed at equalizing the quantity of education available to all." See Michael Yan-lung Luk, "VII. Education in China after the Fall of the Gang of Four: Some Preliminary Observations" in S.K. Chin, ed., The Gang of Four, First Essays after the Fall, Selected Seminar Papers on Contemporary China, II, Centre of Asian Studies, University of Hong Kong, 1977. pp. 107-121.

12. There were a few exceptions at different times in such fields as foreign language, sports, music and fine arts.

13. Pepper, op. cit., (1979) p. 869.

14. In two visits to Beida, (Peking University) in 1972 and 1973 I was told that the university had ten of its own factories on campus and links with another 65 off campus. There was an attempt to link theory and practice in work assignments. For example, chemistry students worked in chemical factories, foreign language students in downtown Peking hotels and stores catering to foreigners. But arts students generally "took society as their laboratory". Philosophy students for example conducted month long social investigations in communes, and history students were involved in oral history projects in production units where they also worked.

15. Pepper, op. cit., (1978), p. 872.

16. Guangming Daily, October 6, 1972.

17. Pepper, op. cit., (1978), p. 868.

18. After visits to four major Chinese universities in 1972 and 1973 (Beida, Qinghua, Nanda and Jungshan) during a diplomatic posting with the Canadian Embassy in Peking, I wrote a lengthy report on them to the Department of External Affairs identifying this retreat, calling the study, "The Reform and Retreat of Chinese Universities." I pointed out that in a number of areas, including teaching methods. the political rhetoric used by Chinese university officials was of ten a great deal more radical than the real thing. However, I may have exaggerated the significance of the 'retreat' and in any event more radical days were yet to come as late 1972 and early 1973 represented a kind of 'false spring' in China generally.

19. Susan L. Shirk, Educational Reform and Political Backlash: Recent Changes in Chinese Educational Policy, Comparative Education Review, Vol. 23, No. 2, June 1979, p. 210.

20. This has not excluded either the creation of special middle schools or a particular emphasis in the curriculum of regular ones appropriate to local needs. For example, China's major oil producing centre Daqing has 592 primary schools and middle schools, the latter of which graduate nearly 10,000 students annually. All students learn about oil, study textbooks on oil now being distributed to schools in other 


\section{W.G. Saywell}

oil-producing areas, and receive lectures from veteran oil workers, geologists and technicians. FE/6080/ B11/10.

21. Pepper, op. cit., (1978) p. 876.

22. A report in "People's Education" which featured a discussion organized by the Ministry of Education in early June and attended by teachers from the Peking area, indicated that the length of schooling was widely discussed and debated, with no consensus reached. Some favoured retaining the 10 year system while others wanted an eleven or twelve year system. While the ten year system was made national in the Cultural Revolution there was fairly widespread experimentation with a five year primary system shortly after Liberation and in 1960 a ten year primary/middle experiment was attempted. FE/6161/BII/8.

23. FE/6985/BII/13.

24. FE/6124/BII/16 May $16,1979$.

25. FE/6119/BII/10.

26. Pepper, op. cit., p. 878.

27. Ibid., p̈p. 876-7.

28. FE/6080/BII/10-11.

29. $\mathrm{FE} / 6131 / \mathrm{BH} / 506$.

30. See for example Jiang Nanxiang's statements as reported in NCNA, May 25, 1979, FE/6128/BII/ 9-12 and Peking radio July 17,1979, Foreign Broadcast Information Service, Daily Report, People's Republic of China, (FBIS) July 20, 1979, 141 pp. L6-L8.

31. Jilin Daily, June 12,1979, FE/6147/BII/12.

32. Suzanne Pepper, China Quarterly, 72, December 1977, p. 815.

33. Clark Kerr, et al, Observations on the Relations Between Education and Work in the People's Republic of China, Report of a Study Group 1978, Berkeley, Carnegie Council on Policy Studies in Higher Education, 1978, p. 93.

34. FE6153/C1/6 Report issued June 27, 1979.

35. Pepper, op. cit., (1977) p. 815-16.

36. Kerr, op. cit., p. 93.

37. FE/6153/C1/6.

38. Pepper, op. cit., (1977) p. 816; FE/6153/C1/6.

39. Ibid.

40. The Clark Kerr study group estimated that students in rural schools may spend $30 \%$ less time in school than American students do although the number of school days for students in metropolitan areas is about the same in both countries Kerr op. cit., p..9.

41. To the earlier well published list of 88 , the Ministry added in the Spring of 1979 the Chinese Medical Science University in Changchun.

42. The figures for 1979 and 1977 come from the June 27, 1979 report of the Statistical Bureau, FE/6153/C1/6. That for 1965 is from Peking Review, February 3, 1978. The 1979 and 1977 figures reveal discrepancies with those given Pepper in $1977(584,000)$ op. cit. (1977) p. 816 and Clark Kerr in $1978(600,000)$ op. cit. p. 93.

43. Kerr, op. cit., p. 8.

44. $\mathrm{FE} / 6153 / \mathrm{C} 1 / 6$.

45. FE $/ 5875 / \mathrm{BII}$.

46. NCNA April 23, 1979, FE/6105/BII/4-6.

47. On August, 1979, Peking radio broadcast an interview with Vice-Minister of Education Gao Yi who referred to the 1979 entrance exams being the second year of unified exams throughout the country. Thus, there must have been some exceptions to the unified nature of the 1977 exams.

48. Renmin Ribao editorial May 17, 1979, FE/6122/BII/10-11.

49. FE/5800/BII/7; FE/5813/BII/12. 
27 Education in China since Mao

50. FBIS/July 11, 1979, 134 pp. L19-20 and FBIS/July 12, 1979, 135: pp. L12.

51. Ibid.

52. Ibid.

53. Saywell interviews. See also FE/6122/BII/10-11.

54. Television-radio-correspondence universities have been opened in a number of provinces. For example, one in Xinjiang was of ficially opened February 17, 1979 (FE/6056/BII/17) and the Shandong radio-television university opened February 6, 1979 (FE/6061/BII/17).

55. NCNA June 13,1978 FBIS E18. One recent visitor was told that candidates could list seven key universities on their lists of choices.

56. This system was described to me in some detail by professors and officials at a leading Chinese university.

57. NCNA April 23, 1979, FE/6105/BII/406.

58. $\mathrm{FE} / 6087 / \mathrm{BII} / 14$.

59. $\mathrm{FE} / 6129 / \mathrm{BII} / 10$.

60. $\mathrm{FE} / 6129 / \mathrm{BII} / 12$

61. $\mathrm{FE} / 6143 / \mathrm{BII} / 5$.

62. NCNA March 23, 1979, FE/6080/BII/9-10.

63. Saywell interview with Ministry of Education, June 1979.

64. These figures were given to me by university officials at these institutions in June, 1979. Other figures given to Ms. Nancy Robinson in the summer of 1979 were 120 graduate students at Langzhou University, 150 graduate students at the Shanghai Teachers University, 150 graduate students at Jungshan University.

65. FE/6143/BII/5.

66. March 15, 1979, FE/6080/BII/11-12.

67. $\mathrm{FE} / 6080 / \mathrm{BII} / 11$.

68. These figures were given to me in visits to these campuses in the winter/spfing of 1973.

69. $\mathrm{FE} / 6102 / \mathrm{BII} / 13$.

70. Pepper, op. cit., p. 822 .

71. $\mathrm{FE} / 6112 / \mathrm{BII} / 14$.

72. $\mathrm{FE} / 6087 / \mathrm{BIJ} / 13$.

73. $\mathrm{FE} / 6061 / \mathrm{BII} / 17$,

74. $\mathrm{FE} / 6091 / \mathrm{BII} / 15$.

75. $\mathrm{FE} / 6091 / \mathrm{BII} / 14$

76. $\mathrm{FE} / 6080 / \mathrm{BII} / 10$.

77. $\mathrm{FE} / 6061 / \mathrm{BII} / 16$.

78. $\mathrm{FE} / 6063 / \mathrm{BII} / 2-3$.

79. FE/6065/BII/16-17.

80. A number of state leaders and editorials have even commented on the risks the present system pose to students' health. For example, in March, 1979 the Minister of Public Health noted an increased frequency of certain diseases among students and cited the pressures created by the new competitive system as the cause. He also pointed out that the state had prescribed the number of hours of sleep a student at each level should get: university : 8 ; middle school: 8 to 9; primary: $9-10$ ! FE/6080/BII/9.

81. Guangming Daily, April 17, 1979, FE/6097/BII/15.

82. For an example of this see a report of Anhui province's Educational Forum in FE/6108/BII/14-15.

83. Renmin Ribao, May 17, 1979, NCNA, FE/6122/BII/7-10.

84. Pepper, op. cit., (1977) p. 823.

85. See for example various provincial radio broadcasts in $\mathrm{FE} / 6112 / \mathrm{BII} / 13$; $\mathrm{FE} / 6108 / \mathrm{BII} / 16$;

FE/6069/BII/11; FE/6124/BII/16; FE/6091/BII/15; AFP May 7, 1979. 